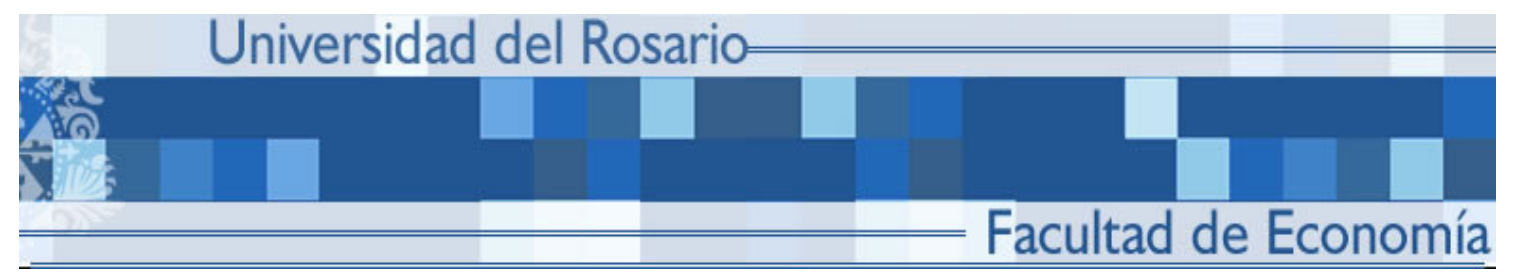

BEYOND THE MINCER EQUATION:

THE INTERNAL RATE OF RETURN TO HIGHER EDUCATION IN COLOMBIA

Andrés Felipe García-Suaza

Juan Carlos Guataquí

José Alberto Guerra

Darío Maldonado 


\title{
Beyond the Mincer Equation: The Internal Rate of Return to Higher Education in Colombia $^{\oplus}$
}

\author{
Andrés Felipe García-Suaza" \\ Juan Carlos Guataquí ${ }^{\star}$ \\ José Alberto Guerra* \\ Darío Maldonado*
}

\begin{abstract}
In order to present an estimation of the Internal Rate of Return (IRR) to higher education in Colombia we take advantage of the methodological approach provided by Heckman, Lochner and Todd (2005). Trying to overcome the criticism that surrounds interpretations of the education coefficient of Mincer equations as being the rate of return to investments in education we develop a more structured approach of estimation, which controls for selection bias, includes more accurate measures of labor income and the role of education costs and income taxes. Our results implied a lower rate of return than the ones found in the Colombian literature and show that the Internal Rate of Return for higher education in Colombia lies somewhere between 0.074 and 0.128 . The results vary according to the year analyzed and individual's gender. This last result reinforces considerations regarding gender discrimination in the Colombian labor market.
\end{abstract}

JEL classification: I28, J11, J31,

Keywords: Education returns, Mincer Equation, Internal Rate of Return, Colombia

\footnotetext{
${ }^{\oplus}$ Las opiniones aquí expresadas son responsabilidad de los autores y por lo tanto no deben ser interpretadas como propias de la Facultad de Economía ni de la Universidad del Rosario.

A Department of Economics, Universidad del Rosario. E-mails: andres.garcia66@urosario.edu.co, jguataqu@urosario.edu.co,jguerra@urosario.edu.co.

* Department of Economics, Universidad del Rosario and CeiBA - Complejidad.

E-mail: dario.maldonadoca@urosario.edu.co
} 


\section{Introduction}

The determinants of wages have been a main concern of the literature on labor economics and on the economics of education since the seminal works of Pareto (1896) and all through the research of Roy (1951), Mincer (1974) and Becker (1964). The Mincer equation has been estimated for different countries, specifications, periods, and data sets. Different econometric techniques have been used in order to avoid selection biases. Concerns for the determinants of wages have been driven by policy considerations. Indeed education and labor market policies depend strongly on whether education (either by additional years of schooling or by completing specific degrees) is a profitable investment and on whether wage differences can be explained by individual characteristics.

Colombia has not been an exception. As in many countries, the returns to education have raised here an enormous interest among scholars and policy makers. A big share of the literature has addressed the returns to education and how these returns behave among individuals with different characteristics. From the Public Economics point of view, an additional issue deals with the possibility of uneven education returns related with features which are not related with the labor productivity of individuals. Scholars in Colombia have also used sophisticated techniques in order to estimate the coefficients of the Mincer equation in such a way that the estimation could avoid the various biases generated in estimations of determinants of earnings. Nevertheless, most studies in Colombia have forgone the fundamental issue of the accurate interpretation of the coefficients of the Mincer equation and to evaluate whether the Mincer specification really captures the shape of the returns to education in Colombia or not. Thereby, on this paper our purpose is to use a methodology proposed by Heckman, Lochner and Todd (2005, HLT from now onwards) in order to provide for the first time an accurate estimation of the value of the Internal Rate of Return of Education in Colombia.

The literature related with estimations of the determinants of wages/earnings in Colombia can be divided in two different waves, and this time gap is mostly due to data availability. The first wave was composed by the papers of Schultz (1968), Selowsky (1968) and Kugler and Reyes (1975). The second wave started with Tenjo (1993a, 1993b), Perfetti (1996), Ribero and Meza (1997), Velásquez (2001), and then evolves to Tenjo and Bernat (2002), Arias and Chaves (2002), Zárate (2003), Nuñez and Sánchez (2003), Mora (2003), Barrero et al. (2004), Tenjo et al. (2005), Prada (2006) and Forero 
and Gamboa (2007), just to mention the most well-known references. The papers in the first wave were concerned with the effect of education levels over wages and used the OLS technique. The papers in the second wave introduced different considerations on estimating the determinants of earnings: the biases that the OLS techniques introduce in the Mincer equation coefficients, possible interactions of individual characteristics (i.e. gender, economic sector or geographic criteria) and education level, or non-linear forms of the relation between the log of income and education.

It must be said that, as argued by HLT for international studies, most Colombian studies have not been careful enough in the way they approach their estimations or in the way they interpret their results. Strictly, the coefficient that accompanies the level of education in the Mincer equation is the Wage Growth Rate with respect to Education $(\mathrm{GRE})^{1}$. This is a radical departure point. Most papers have argued that this coefficient (usually measured as years spent at school) is the Internal Rate of Return (IRR) to education. It must be remarked that this identity (IRR being GRE) only holds under very restrictive assumptions. They are i) the linearity of the (log of) wage in schooling, ii) parallelism: restriction that log earnings - experience profiles are parallel across schooling levels (i.e. multiplicative separability between schooling and experience components of earnings), iii) length of working life does not depend on the schooling levels, and iv) absence of income taxes, and financial and psychological costs of education. Although most studies correctly estimate the rate of growth of labor income with respect to education level, if their estimation does not hold for these assumptions, their interpretation becomes difficult.

It is paramount to understand the implications of these concepts. GRE can only be analyzed as the IRR if the four previous assumptions are satisfied, which does not happen to be the standard, empirical case. This identity becomes even more difficult to hold when we have to analyze variability over time. Indeed, GRE is one component of IRR, but this last concept implies more determinants. GRE can be taken as an expression of the way education has an influence over labor income, but it falls short of being the accurate expression of the way a financial project devoted to invest in education can be evaluated. Paraphrasing, GRE is a component of IRR, but an accurate IRR has to include more information and variables in order to be judged as radical criteria for education investment decisions.

\footnotetext{
${ }^{1}$ This term also holds as the semi-elasticity of wage with respect to education level.
} 
This paper reconsiders the estimation of wage determinants by using the HLT approach to accurately calculate the IRR in Colombia, using data from the Household Surveys (Encuesta de Hogares) for the years 2001 to 2005. Following HLT we need to consider not only the information from the household surveys but we also need to include information about the costs of education and of the tax system in Colombia. The information of household surveys in Colombia do not provide information about costs of education or tax payments at the individual level; our approach uses average tuition fees and potential income tax payments to solve this issue. Furthermore, for our purpose we also require to consider more flexible wage equations that allow for non-linearities of (the log of) wage in education.

In order to approach our research framework, let's consider the following landscape. An individual of 16 years old has finished high school. Based on purely economic factors (leaving aside any consideration of utility costs or benefits of education) why should this individual acquire additional education? Our assumption, as in most of the literature on the subject, is that this individual will attend university if the IRR associated to the university degree is higher than its discount rate. Thereby, in order to appropriately study this problem, one needs to calculate accurately the IRR.

Our results show that the Internal Rate of Return for higher education in Colombia lies somewhere between 0.074 and 0.128 . The results vary according to the year analyzed and individual's gender. This last result reinforces considerations regarding gender discrimination in the Colombian labor market.

\section{The Internal Rate of Return to Education}

Mincer's earnings model is one of the cornerstones of labor economics (see Grossbard, 2006). It has been mainly used to analyze the effect of investment in different forms of human capital and to decompose the effect of different socioeconomic features over earnings. Two recent literature reviews (Lemieux, 2003; Heckman et al., 2003) provided critical overviews of the studies that have used this famous equation and their methodological evolution. Both papers recognize its power as a statistical instrument quite capable to predict wages. However, Heckman et al. argue that there are better specifications for the functional form, which may yield more accurate predictions of wages. More important than the specific functional form that is used to estimate earnings is the interpretation that can be given to the coefficients of the variables 
included in the equations. If these coefficients have an important economic meaning, the specification should stick to specifications that illustrate those meanings. However if, as argued by HLT, the coefficients of the Mincer equation do not have an important economic meaning: one could resort to different specifications and use the Mincer equation as a tool to predict wages; these predictions can be used for economic analysis.

Introducing our considerations, the seminal, most known Mincer equation can be expressed as follows:

$\operatorname{Ln}\left[w_{i}(s, x)\right]=\alpha_{0}+\rho_{s} s_{i}+\beta_{0} x_{i}+\beta_{1} x_{i}^{2}+\varepsilon_{i}$.

Where $w(s, x)$ represents wage, $s$ represents years of education, $x$ stands for experience (measured in years) and $\varepsilon$ is the error term. Many authors have interpreted $\rho_{s}$ as the Internal Rate of Return to Education (IRR). This stems from the original idea of Mincer (1974, chapter 1) where this function was presented for the first time. Nonetheless, Mincer was already aware of the assumptions required to portrait this parameter as the IRR. In particular he points out that $\rho_{s}$ can be only be seen as the IRR if the log of wages is linear in education, all individuals face labor market lives of the same length, there are no psychological or economic costs of education and there are no income taxes. If any of these assumptions fails to hold, one has to interpret $\rho_{s}$ simply as the rate of growth of wage with respect to education. If $\rho_{s}$ only stands this way, it cannot be seen as the main parameter guiding decisions about additional education by rational individuals.

If the stated assumptions fail, this may arise from two specific reasons. They must be taken account in order to approach an alternative way to circumvent the situation and provide an accurate estimation of the IRR of education. The first is related to the functional form chosen by Mincer. The second is the need to include additional information in the computation of the IRR of education. In our analysis we will address both issues. Regarding the first problem we will follow HLT and use extended parametric forms of the Mincer equation as well as a non parametric estimations. These equations are used to estimate yearly wages along the life cycle of individuals with 
different education levels and these estimations are used to calculate the IRR of education using traditional algebraic techniques. Regarding the second problem we include in our statistical analysis additional information to capture the effect of income taxes on wages and the effect of direct economic costs of education on the decision to attend university.

\section{Data}

Our exercises use data from three different sources. First we use Colombian Household surveys for the years 2001 to 2005. This data bases give information about wages, education level, and age (which we use as proxy for experience). We will restrict our analysis to data from the 13 main cities in Colombia and we will only use urban data; these restrictions allow us to be confident that reported wage corresponds to returns to human capital rather than to returns to other types of capital. An alternative exercise was developed using the specific information contained on the 2003 Quality of Life Standards Survey (ECV) regarding technical education as compared with formal education.

As Colombian household surveys do not include information about the tuition fees that current workers actually paid when they attended college, we use information collected in 2006 by economic magazine La Nota Económica, which comprises the tuition fee for most private and public universities in Colombia by undergraduate program of study. This is our second data source. Finally, using the income tax tables according to yearly wage, we calculate the amount of taxes that should be paid by each worker and its wage level. We also include other contributions made by employers and employees as part of perceived wage (more details on this calculation are included in the appendix).

\section{Estimation Method and Results}

Our goal is to have an accurate estimate of the IRR of higher education in Colombia. Under the assumptions of constant labor supply, risk neutrality and neutrality to consumption inequality over time, the Internal Rate of Return of finishing higher education versus obtaining only secondary education degree is given by equation (2):

$$
\sum_{t=s_{u}}^{T_{u}} Y_{u}(x) \frac{1}{(1+\tilde{r})^{t}}-\sum_{t=0}^{s_{u}} C_{u} \frac{1}{(1+\tilde{r})^{t}}=\sum_{t=s_{s}}^{T_{s}} Y_{s}(x) \frac{1}{(1+\tilde{r})^{t}}-\sum_{t=0}^{s_{s}} C_{s} \frac{1}{(1+\tilde{r})^{t}} .
$$


This equation equates the present value of net returns of university education (left handside) with the present value of the net benefits of high school education (right handside). In this equation $Y_{e}(x)$ represents the yearly wage of an individual with education level $e$ and $x$ years of experience, according to the Mincer estimation; $C_{e}$ is per year tuition fee associated to an education level $e$. Following this, $s_{e}$ represents the number of years need to finish education level $e$ and $T_{e}$ represents the retirement age of an individual with $e$ education level, $t$ represents the year and $\tilde{r}$ represents the IRR. This equation is used to find the value of $\tilde{r}$ that solves the equation. If the $\tilde{r}$ that solves this equation is higher than the discount rate of the individual it is worth for her to attend higher education; otherwise she would rather stop education at high school level. Since in equilibrium the discount rate must be equal to the economy's interest rate, $\tilde{r}$ can be seen as a measure of the profitability of education.

As we are unable to argue that $\tilde{r}$ is equal to the coefficient that accompanies education in the simple Mincer equation, we use a two-stage procedure. In the first stage we estimate wages. In the second stage, using estimated yearly wages of individuals with different education profiles we will compute the IRR as the result of the equation (2). For the estimation of the wage equations we take three different approaches. First we use the traditional Mincer equation where the relation between wage and education is linear. Second, in order to consider possible non linearities of wage in education and hours of work (HLT argue that this may be the case) we use a modified Mincer equation in which we also include reported hours worked during the month, gender, and splines for education level. We estimate this equation using simple OLS and correcting for selection bias using the traditional method of Heckman (1979). The selection equation we use estimates the probability of not having zero income in the period in which the estimation is done; those individuals with zero income are either unemployed ones or individuals who have decided not to participate in the labor market (Co et al., 2002). The underlying assumption behind the estimation when selection bias is included is that when individuals compute their expected wage they consider the possibility of either being unemployed or of not to participate in the labor market at all; when selection bias is not considered to compute expected wages, individuals actually would be dismissing these possibilities. The third approach is to use a non parametric estimation of the 
Mincer equation. Through a non-parametric estimation of earnings we relax the Mincer restrictions and we do not impose any additional assumption, other than continuity on the relationship between earnings and experience. On this sense, wage is estimated as a function of experience for each schooling level, separated by gender

All estimations were made using reported wages (before tax wages, for our purposes) and we compute after tax wages applying to those the income taxes that should be paid according to the Colombian tax $\operatorname{code}^{2}$. To this after tax wage we have added the expected employer's contribution to worker's pension. Since we are using theoretical tax payments our results may understate the IRR perceived by individuals. As we have argued, we are not interested in the particular results (determinants) that may arise from the estimation of the wage equations. The interested reader can find these results on the tables at the end of the article. Graphs with the results of the non-parametric estimations are also included in the appendix.

We concentrate now on the IRR that arises from our exercises. Using estimated wages for each year of experience and for the two education levels concerned (high school and undergraduate university), and tuition fees obtained from the data base constructed by La Nota Económica we use traditional algebraic procedures to compute $\tilde{r}$ by using equation (2).

We calculate the IRR for college education for those individuals who happened to posses this degree and were included in the Colombian Households Surveys applied between 2001 and 2005; we compute the IRR for each year and we also do it using a pooled regression for the period as a whole. This last exercise allows us to eliminate the economic cycle effects and to concentrate on the structural features through which the Colombian labor market rewards investments on higher education.

Table 1 shows the results of the IRR calculated using parametric estimations of the wage equation. From this table we can outline the following issues: a structural gender discrimination pattern, as the IRR for males is higher than for females (although this difference is never higher than 0.0044. Second, the IRR happens to be quite stable over time. Third, the impact of taxes on the IRR is very low; maybe this is a result of failures

\footnotetext{
${ }^{2}$ Two definitions of wages were built, as follows: before-tax wages consist in the sum of reported wages and the share of pensions/retirement fund payment that the employers must provide; and after-tax wages are the above definition with income taxes discounted according National Taxes Directorate.
} 
on the design of the Colombian tax code. Fourth, the IRR is effectively affected by the way wages are estimated. Finally, something similar happens with the difference between the estimates when using the OLS equations or the ones that correct for selfselection.

Table 1: IRR - Parametric OLS estimation - Household Survey Data

\begin{tabular}{|c|c|c|c|c|c|c|c|}
\hline \multicolumn{8}{|c|}{ Parametric OLS estimation - before tax wages } \\
\hline Specification & Gender & 2001 & 2002 & 2003 & 2004 & 2005 & Pooled \\
\hline \multirow{2}{*}{ Mincer } & Female & 0.0779 & 0.0842 & 0.0744 & 0.0762 & 0.0746 & 0.0768 \\
\hline & Male & 0.0821 & 0.0852 & 0.0783 & 0.0813 & 0.0790 & 0.0811 \\
\hline \multirow{2}{*}{$\begin{array}{l}\text { Modified } \\
\text { Mincer }\end{array}$} & Female & 0.0759 & 0.0777 & 0.0758 & 0.0679 & 0.0702 & 0.0732 \\
\hline & Male & 0.0801 & 0.0815 & 0.0798 & 0.0727 & 0.0745 & 0.0774 \\
\hline \multicolumn{8}{|c|}{ Parametric OLS estimation - after tax wages } \\
\hline Specification & Gender & 2001 & 2002 & 2003 & 2004 & 2005 & Pooled \\
\hline \multirow{2}{*}{ Mincer } & Female & 0.0764 & 0.0798 & 0.0729 & 0.0747 & 0.0730 & 0.0752 \\
\hline & Male & 0.0805 & 0.0835 & 0.0767 & 0.0796 & 0.0773 & 0.0794 \\
\hline \multirow{2}{*}{$\begin{array}{l}\text { Modified } \\
\text { Mincer }\end{array}$} & Female & 0.0753 & 0.0745 & 0.0755 & 0.0676 & 0.0699 & 0.0728 \\
\hline & Male & 0.0794 & 0.0811 & 0.0793 & 0.0723 & 0.0741 & 0.0769 \\
\hline \multicolumn{8}{|c|}{ Parametric OLS estimation with selection bias correction - before tax wages } \\
\hline Specification & Gender & 2001 & 2002 & 2003 & 2004 & 2005 & Pooled \\
\hline \multirow{2}{*}{ Mincer } & Female & 0.0783 & 0.0820 & 0.0750 & 0.0765 & 0.0743 & 0.0771 \\
\hline & Male & 0.0806 & 0.0834 & 0.0767 & 0.0793 & 0.0766 & 0.0792 \\
\hline \multirow{2}{*}{$\begin{array}{l}\text { Modified } \\
\text { Mincer }\end{array}$} & Female & 0.0786 & 0.0809 & 0.0783 & 0.0705 & 0.0720 & 0.0756 \\
\hline & Male & 0.0810 & 0.0826 & 0.0802 & 0.0735 & 0.0745 & 0.0780 \\
\hline \multicolumn{8}{|c|}{ Parametric OLS estimation with selection bias correction - after tax wages } \\
\hline Specification & Gender & 2001 & 2002 & 2003 & 2004 & 2005 & Pooled \\
\hline \multirow{2}{*}{ Mincer } & Female & 0.0768 & 0.0803 & 0.0735 & 0.0749 & 0.0726 & 0.0755 \\
\hline & Male & 0.0790 & 0.0817 & 0.0751 & 0.0776 & 0.0748 & 0.0775 \\
\hline \multirow{2}{*}{$\begin{array}{l}\text { Modified } \\
\text { Mincer }\end{array}$} & Female & 0.0780 & 0.0806 & 0.0778 & 0.0701 & 0.0716 & 0.0752 \\
\hline & Male & 0.0803 & 0.0821 & 0.0797 & 0.0730 & 0.0741 & 0.0775 \\
\hline
\end{tabular}

Source: Authors' estimations.

Table 2 shows the IRR as computed from non parametric estimates of the wage equation. Here, the gender gap holds as well and the IRR stays stable over time as well. One remarkable fact here is that the IRR (non parametric techniques approach one) happens to be higher than the one we obtained from using wages estimated from parametric estimation. By comparing the non parametric estimation with the modified version of the Mincer equation we get an idea of the importance of the bias when separability of earnings in schooling and experience is assumed (i.e. parallelism). This difference is of the order of 0.04 .

Table 2: IRR - Non parametric estimation - Household Survey data

\begin{tabular}{lllllll}
\hline \multicolumn{6}{c}{ Non Parametric estimation - before tax wages } \\
\hline Gender & 2001 & 2002 & 2003 & 2004 & 2005 & Pooled \\
\hline
\end{tabular}




\begin{tabular}{ccccccc}
\hline Female & 0.1066 & 0.1057 & 0.0984 & 0.0987 & 0.0985 & 0.1012 \\
Male & 0.1279 & 0.1236 & 0.1155 & 0.1119 & 0.1138 & 0.1179 \\
\hline \multicolumn{7}{c}{ Non Parametric estimation - after tax wages } \\
\hline Gender & $\mathbf{2 0 0 1}$ & $\mathbf{2 0 0 2}$ & $\mathbf{2 0 0 3}$ & $\mathbf{2 0 0 4}$ & $\mathbf{2 0 0 5}$ & Pooled \\
\hline Female & 0.1049 & 0.1041 & 0.0974 & 0.0972 & 0.0970 & 0.0997 \\
Male & 0.1248 & 0.1211 & 0.1124 & 0.1090 & 0.1113 & 0.1151 \\
\hline
\end{tabular}

Source: Authors' estimations.

An alternative exercise is shown in Tables 3 and 4, which have been made taking advantage of some specific information contained in the 2003 Quality of Life Standards Survey (ECV). As on this survey individuals are requested to provide specific information about technical (non-formal) education we can compare the IRR obtained by individuals with technical training as compared with those ones who have formal, academic, high-school and bachelor degrees. As for all the remaining estimations, these ones happen to show a discriminatory gender gap as for all the education levels, the male IRR happens to be higher than the female one. On terms of education policy, it is important to emphasize that technical education has become an interesting option that the Colombian labor market seems to be rewarding increasingly.

Table 3: IRR - Parametric estimation - Quality of Life Survey Data

\begin{tabular}{|c|c|c|c|c|}
\hline \multicolumn{5}{|c|}{ Parametric estimation - before tax wages } \\
\hline $\begin{array}{c}\text { Education } \\
\text { Level }\end{array}$ & Specification & Gender & OLS & OLS + SS \\
\hline \multirow{4}{*}{$\begin{array}{c}\text { High school } \\
\text { vs. Technical } \\
\text { Training }\end{array}$} & \multirow{2}{*}{ Mincer } & Female & 0.0902 & 0.0884 \\
\hline & & Male & 0.0969 & 0.0930 \\
\hline & \multirow{2}{*}{$\begin{array}{l}\text { Modified } \\
\text { Mincer }\end{array}$} & Female & 0.0570 & 0.0494 \\
\hline & & Male & 0.0633 & 0.0535 \\
\hline \multirow{4}{*}{$\begin{array}{l}\text { High school } \\
\text { vs. University }\end{array}$} & \multirow{2}{*}{ Mincer } & Female & 0.0756 & 0.0758 \\
\hline & & Male & 0.0831 & 0.0811 \\
\hline & \multirow{2}{*}{$\begin{array}{l}\text { Modified } \\
\text { Mincer }\end{array}$} & Female & 0.0898 & 0.0924 \\
\hline & & Male & 0.0980 & 0.0980 \\
\hline \multirow{4}{*}{$\begin{array}{c}\text { Technical } \\
\text { Training vs. } \\
\text { University }\end{array}$} & \multirow{2}{*}{ Mincer } & Female & 0.0637 & 0.0650 \\
\hline & & Male & 0.0716 & 0.0708 \\
\hline & \multirow{2}{*}{$\begin{array}{l}\text { Modified } \\
\text { Mincer }\end{array}$} & Female & 0.1081 & 0.1175 \\
\hline & & Male & 0.1182 & 0.1250 \\
\hline & \multicolumn{4}{|c|}{ Parametric estimation - after tax wages } \\
\hline $\begin{array}{c}\text { Education } \\
\text { Level }\end{array}$ & Specification & Gender & OLS & OLS + SS \\
\hline \multirow{4}{*}{$\begin{array}{l}\text { High school } \\
\text { vs. Technical } \\
\text { training }\end{array}$} & \multirow{2}{*}{ Mincer } & Female & 0.0892 & 0.0875 \\
\hline & & Male & 0.0959 & 0.0920 \\
\hline & \multirow{2}{*}{$\begin{array}{l}\text { Modified } \\
\text { Mincer }\end{array}$} & Female & 0.0569 & 0.0493 \\
\hline & & Male & 0.0631 & 0.0534 \\
\hline \multirow{4}{*}{$\begin{array}{l}\text { High school } \\
\text { vs. University }\end{array}$} & \multirow{2}{*}{ Mincer } & Female & 0.0745 & 0.0746 \\
\hline & & Male & 0.0819 & 0.0799 \\
\hline & \multirow{2}{*}{$\begin{array}{l}\text { Modified } \\
\text { Mincer }\end{array}$} & Female & 0.0892 & 0.0917 \\
\hline & & Male & 0.0973 & 0.0974 \\
\hline
\end{tabular}




\begin{tabular}{ccccc}
\hline \multirow{2}{*}{ Technical } & \multirow{2}{*}{ Mincer } & Female & 0.0625 & 0.0637 \\
training vs. & & Male & 0.0702 & 0.0694 \\
\cline { 2 - 5 } University & Modified & Female & 0.1073 & 0.1166 \\
& Mincer & Male & 0.1173 & 0.1241 \\
\hline
\end{tabular}

Source: Authors' estimations.

Table 4: IRR - Non-parametric estimation - before tax wages - Quality of Life Survey Data

\begin{tabular}{|c|c|c|}
\hline \multicolumn{3}{|c|}{ Non-parametric estimation - before tax wages } \\
\hline Education Level & Gender & \\
\hline \multirow{2}{*}{$\begin{array}{l}\text { High school vs. Technical } \\
\text { training }\end{array}$} & Female & 0.0209 \\
\hline & Male & 0.0414 \\
\hline \multirow{2}{*}{ High school vs. University } & Female & 0.0478 \\
\hline & Male & 0.0613 \\
\hline \multirow{2}{*}{$\begin{array}{c}\text { Technical training vs. } \\
\text { University }\end{array}$} & Female & 0.0615 \\
\hline & Male & 0.0718 \\
\hline \multicolumn{3}{|c|}{ Non-parametric estimation - after tax wages } \\
\hline Education Level & Gender & \\
\hline \multirow{2}{*}{$\begin{array}{l}\text { High school vs. Technical } \\
\text { training }\end{array}$} & Female & 0.0203 \\
\hline & Male & 0.0402 \\
\hline \multirow{2}{*}{ High school vs. University } & Female & 0.0461 \\
\hline & Male & 0.0572 \\
\hline \multirow{2}{*}{$\begin{array}{l}\text { Technical training vs. } \\
\text { University }\end{array}$} & Female & 0.0593 \\
\hline & Male & 0.0664 \\
\hline
\end{tabular}

Source: Authors' estimations.

Finally, we can use the results from Tables 1 and 2 and compare them with the results presented on Table 5. From this comparison it is clear the quantitative differential effect generated by wrongly interpreting the GRE as the IRR, and perhaps thereby overstating the returns of education. The comparison shows that the IRR is quite lower than the GRE and reinforces the results obtained by HLT: the GRE overestimates returns to education and is usually higher than the IRR.

Table 5: Growth rate of wages with respect to education - parametric OLS estimation - Household Survey Data

\begin{tabular}{ccccccc}
\hline \multicolumn{7}{c}{ Before tax wages } \\
\hline Specification & 2001 & 2002 & 2003 & 2004 & 2005 & Pooled \\
\hline Mincer & 0.1313 & 0.1439 & 0.1335 & 0.1406 & 0.1347 & 0.1369 \\
\hline $\begin{array}{c}\text { Modified } \\
\text { Mincer }\end{array}$ & 0.1953 & 0.2069 & 0.2024 & 0.1782 & 0.1860 & 0.1937 \\
\hline \multicolumn{7}{c}{ Before tax wages } \\
\hline Specification & $\mathbf{2 0 0 1}$ & $\mathbf{2 0 0 2}$ & $\mathbf{2 0 0 3}$ & $\mathbf{2 0 0 4}$ & $\mathbf{2 0 0 5}$ & Pooled \\
\hline Mincer & 0.1291 & 0.1413 & 0.1313 & 0.1381 & 0.1322 & 0.1345 \\
\hline $\begin{array}{c}\text { Modified } \\
\text { Mincer }\end{array}$ & 0.1952 & 0.2070 & 0.2022 & 0.1785 & 0.1860 & 0.1937 \\
\hline \multicolumn{7}{c}{ Corrected for self-selection } \\
\hline
\end{tabular}




\begin{tabular}{ccccccc}
\hline Specification & 2001 & 2002 & 2003 & 2004 & 2005 & Pooled \\
\hline Mincer & 0.1255 & 0.1361 & 0.1267 & 0.1322 & 0.1267 & 0.1295 \\
\hline $\begin{array}{c}\text { Modified } \\
\text { Mincer }\end{array}$ & 0.1831 & 0.1894 & 0.1821 & 0.1597 & 0.1678 & 0.1761 \\
\hline Source: Authors' estimations. & & & &
\end{tabular}

Source: Authors' estimations.

In order to evaluate the implications of the IRR that we have estimated we need to make some specific comparisons, considering investment in higher education as a financial project and its potential reward compared with any other financial investment. In order to do so we took two different interest rates for Colombia and compared them with our IRR estimates. The first rate was the DTF (Fixed Term Interest Rate), which is a fixed, low risk kind of interest rate and is calculated as the weighted average of the interest rate to be paid to fix-term (90 days) deposit certificates in Colombia, and we calculated it to have a real average level of $5 \%$ for the last ten years. The second interest rate was the natural interest rate for Colombia, which is $4 \%$, according to Misas et al. (2006). Clearly general university education is a high return investment in Colombia. Even the lowest of our estimates of the IRR is higher than the Colombian DTF; the smallest difference is of more than 1 percent point. However, our estimates of the IRR for technical university education are not always higher than the Colombian DTF, nor than the Colombian natural interest rate (see Table 4). This last conclusion shows the importance of developing more research that links the specificity of technical education in Colombia and the labor market for individuals with technical education to its returns.

\section{Final remarks}

Following methodological criticism to the recurrent interpretation of the education coefficient of Mincer earning/wages equation as the Internal Rate or Return for investments in education, we have addressed the issue of providing an accurate estimation of the Internal Rate of Return to Higher Education in Colombia, by using the method proposed by Heckman, Lochner and Todd (2005). Our results reinforce the idea that an inaccurate interpretation of the GRE as the IRR actually overestimates the potential returns of investments in education for Colombia.

We must point out that in order to obtain our estimates of the IRR we have made a number of potentially restrictive assumptions, mainly related with behavior towards risk and inequality on lifetime consumption. Further research will take account of these 
assumptions. An additional topic which is worth exploring by using the HLT approach is the impact that different financial mechanisms may have over the IRR.

For Colombia, as for many other countries, both theoretical and data availability issues have guided the evolution of the application of the Mincer model. Data availability may be the main factor to be taken account in order to explain the surge of two different waves of studies (1970-80s vs. 1990s onwards). Due to wider, public availability of data, theoretical issues have become the most dynamic force of recent innovations on the literature. We have tried to provide a conclusive exercise by combining an application of these theoretical issues and data strategy.

On Human Capital Theory sense, the Internal Rate of Return to Education can be seen as a measure of the profitability of investment in education. According to our estimations, higher education, both college and technical one, in Colombia, provides positive returns, which, nonetheless, seem to posses a gender gap and a negative effect of income taxes over returns of investment on education. We attribute this negative effect to the specific design of the Colombian tax code, a hypothesis that obviously requires further research. 


\section{References}

Arias, Y., Chávez, A. 2002. "Cálculo de la Tasa Interna de Retorno de la Educación en Colombia." Documento de Trabajo No. 2. Universidad Externado de Colombia: Bogotá.

Barrero, A., Vélez, C., López, I., Rosales, R. y Mogollón D. 2004. "Evaluación económica del componente educativo del programa familias en acción del Plan Colombia”. Documento CEDE 2004-39. Universidad de Los Andes: Bogotá.

Becker, G. 1964. Human Capital: A Theoretical and Empirical Analysis with Special Reference to Education. New York: NBER - Columbia University Press.

Co, C. Y., Gang, I. and M. Yun. 2002. "Self-Employment and Wage Earning: Hungary during Transition." IZA Discussion Paper Series No. 572. Institute for the Study of Labor.

Forero, N., Gamboa, L. 2007. "Cambios en los Retornos de la Educación en Bogotá entre 1997 y 2003." Lecturas de Economía, 66.

Heckman, J. 1979. "Sample Selection Bias as a Specification Error." Econometrica, 47:1.

Heckman, J., Lochner, L. and P. Todd. 2005. "Earnings Functions, Rates of Return and Treatment Effects: The Mincer Equation and Beyond." NBER Working Paper Series No. 11544. NBER.

Heckman, J., Lochner, L. and P. Todd. 2003. "Fifty Years of Mincer Earnings Regressions." NBER Working Paper Series No. 9732. NBER.

Lemieux, T. 2006. ""The Mincer Equation" Thirty Years after Schooling, Experience and Earnings," in Jacob Mincer: A Pioneer of Modern Labor Economics. S. Grossbar ed: Springer.

Kugler, B., Reyes, A. 1975. "Educación y Mercado de Trabajo Urbano en Colombia: Una Comparación entre Sectores Modernos y No Modernos." CCRP: Bogotá.

Mincer, J. 1974. Schooling, Experience and Earnings: Columbia University Press - NBER.

Mora, J. 2003. "Sheepskin Effects and Screening in Colombia." Colombian Economic Journal, 1. 
Nuñez, J., Sánchez, F. 2003. "A Dynamic Analysis of Human Capital, Female Work-Force Participation, Returns to Education and Changes in Household Structure in Urban Colombia, 1976-1998." Colombian Economic Journal, 1.

Pareto, V. 1896. "La courbe de la répartition de la richesse." Recueil Publié par la Faculté de Droit: Lausanne.

Perfetti, M. 1996. "Diferencias Salariales entre Hombres y Mujeres No Asalariados durante el periodo 1984-1994." Planeación y Desarrollo, 27.

Prada, C. 2006. ¿¿Es Rentable la Decisión de Estudiar en Colombia?." Ensayos de Política Económica, 51.

Ribero, R., Meza, C. 1997. "Ingresos Laborales de Hombres y Mujeres en Colombia: 1976 - 1995." Archivos de Macroeconomía No. 62. Departamento Nacional de Planeación: Bogotá.

Roy, A. D. 1952. "Some Thoughts on the Distribution of Earnings." Oxford Economic Papers, 3:2.

Schultz, T. 1968. "Returns to Education in Bogota." RM5645. Rand Corporation - AID.

Selowsky, M. 1968. "The Effect of Unemployment Labor-Market Segmentation and the Returns to Educated: The Case of Colombia" Centre for International Affairs. Harvard University: Boston.

Tenjo, J. 1993a. "Educación, habilidad, conocimientos e ingresos." Planeación y Desarrollo, 24.

Tenjo, J. 1993b. "Evolución a la Inversión en Educación 1976 - 1989." Planeación y Desarrollo, 24.

Tenjo, J., Bernat, L. 2002. "Evolución de las Diferencias Salariales entre Hombres y Mujeres: Comparación de Seis Países Latinoamericanos."

Tenjo, J., Bernal, R. and L. Bernat. 2005. "Evolución de las Diferencias Salariales entre Hombres y Mujeres: Comparación de Seis Países Latinoamericanos, Un Intento de Interpretación." Documento CEDE No. 18. Universidad de los Andes: Bogotá.

Zárate, H. 2003. "Cambios en la Estructura Salarial: Una Historia desde la Regresión Cuantílica." Borradores de Economía No. 245. Banco de la República: Bogotá.

Various. 2006. "Guía de las Mejores Universidades." La Nota Económica: Bogotá. 
Velásquez, C. 2001. Análisis empírico de las diferencias salariales entre hombres y mujeres en Colombia. Universidad del País Vasco. 


\section{Appendix: Non parametric estimation for Age Before-tax wage profiles using}

\section{Locally Weighted Scatter-plot Smoothing (LOWESS)}

2001

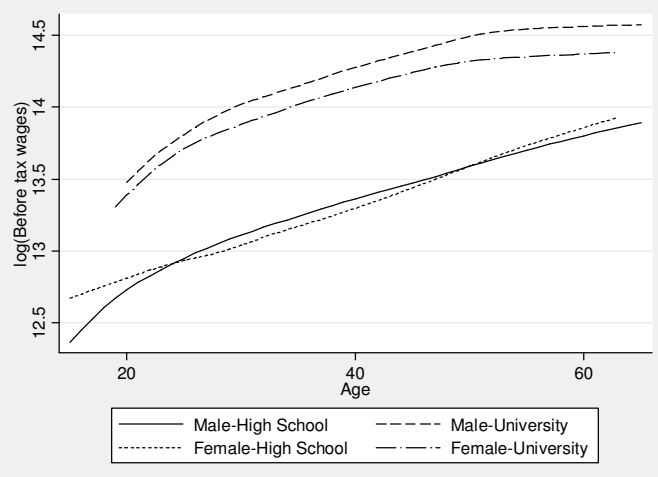

2003

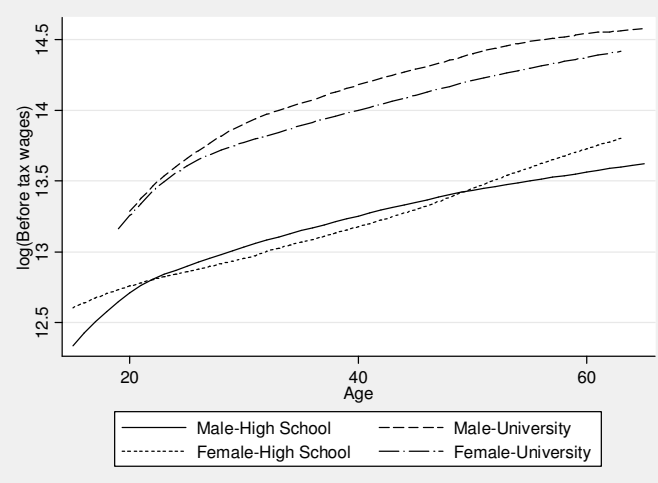

2005

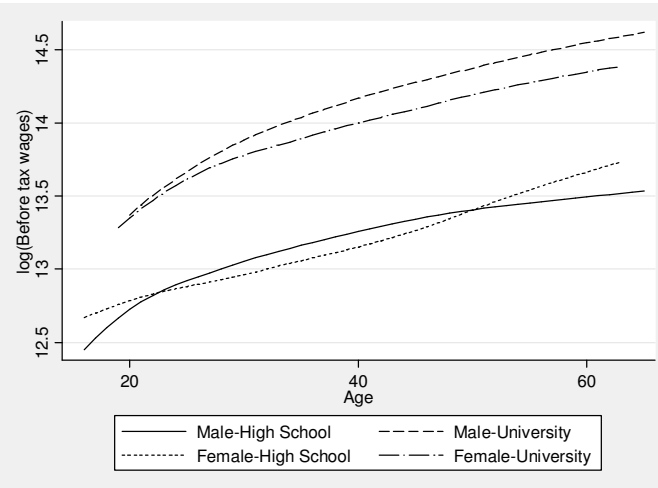

2002

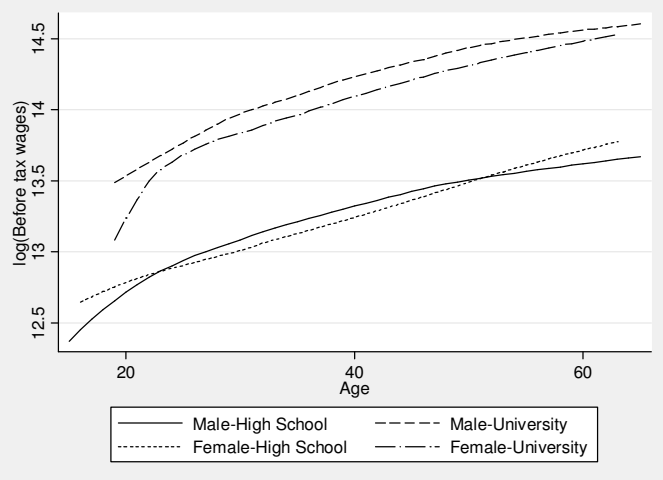

2004

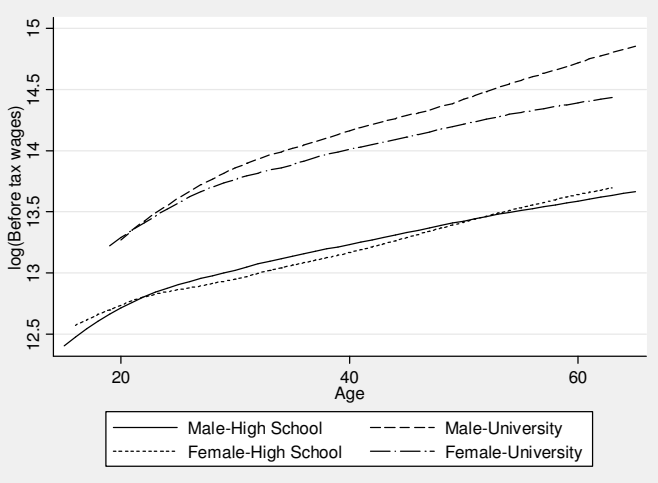

2001-2005

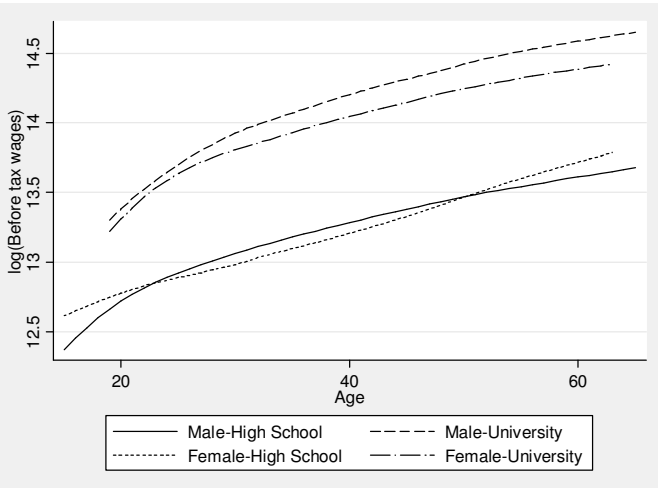




\section{Appendix: Non parametric estimation for Age After-tax wage profiles using Locally Weighted Scatter-plot Smoothing (LOWESS)}

2001

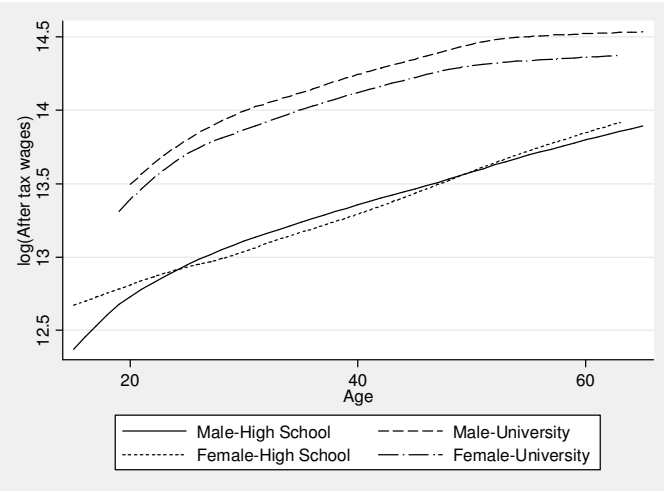

2003

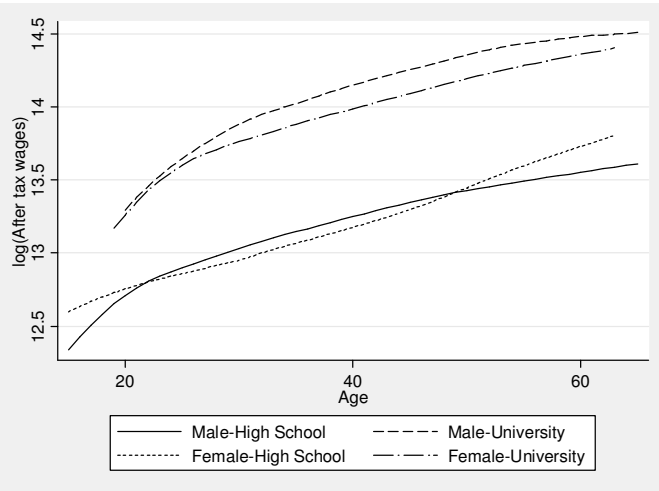

2005

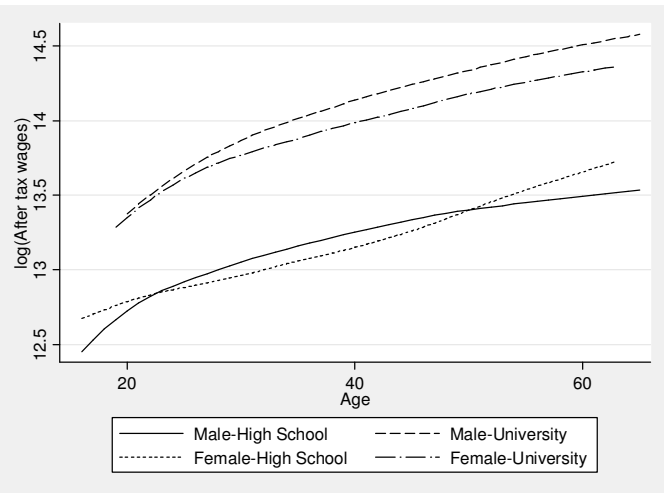

2002

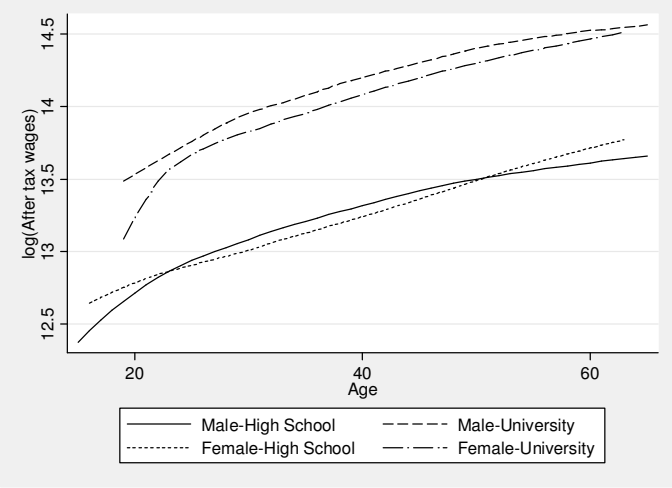

2004

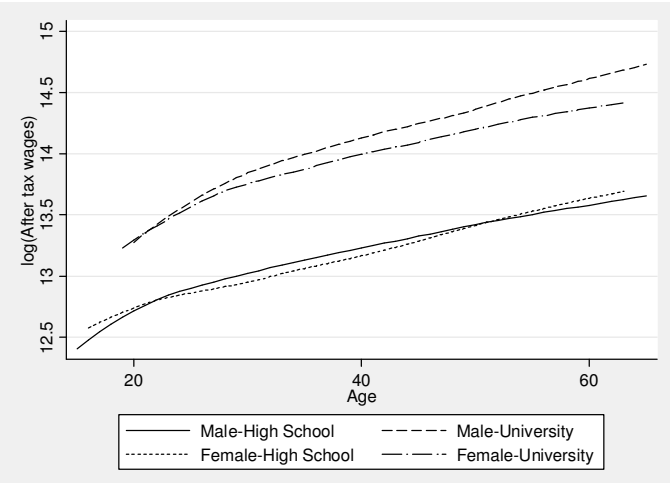

2001-2005

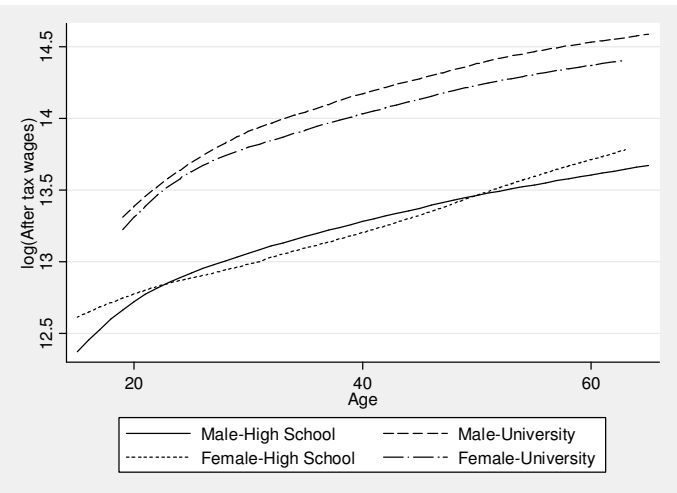

